\title{
Financial Linkages and Active Poor Access to Microcredit in Tanzania and Kenya
}

\author{
Isidore Minani $^{1} \&$ Esther K. Ishengoma ${ }^{2}$ \\ ${ }^{1}$ Faculty of Business and Management Sciences, Ruaha Catholic University, Iringa, Tanzania \\ ${ }^{2}$ University of Dar es Salaam Business School, University of Dar es Salaam, Dar es Salaam, Tanzania \\ Correspondence: Isidore Minani, Faculty of Business and Management Sciences, Ruaha Catholic University, \\ Iringa, Tanzania.
}

Received: December 8, 2017

Accepted: December 17, 2017

Online Published: December 28, 2017

doi:10.20849/iref.v1i1.271

URL: https://doi.org/10.20849/iref.v1i1.271

\begin{abstract}
This study explores the role of financial linkages in mitigating barriers to rural active poor access to microcredit in Tanzania and Kenya. Through the interview to 34 Microfinance institutions and their 74 clients selected from Tanzania and Kenya, the exploratory research using the Content Analysis technique established that financial linkages have significantly contributed in increasing MFIs loanable funds. However, they have not mitigated the barriers to microcredit access including the types and size of collaterals, mandatory savings/deposits amount, higher-than-market interest rates, hidden charges, unbending repayment arrangement, short grace period and inflexible initial loan size which are among key barriers to rural active poor to access microcredit despite its availability. Findings implication appeals for objective national microfinance policy revisit to address aforementioned barriers in both countries if the sector is to benefit the rural active poor.
\end{abstract}

Keywords: financial linkages, microcredit, access, microfinance institutions

\section{Introduction}

Financial linkages have certainly increased the scope and scale of microcredits offered by microfinance institutions (MFIs). However, millions of rural active poor in Tanzania and Kenya still do not have access to them. The debate over the potential of financial linkages to influence microcredit accessibility to the rural active poor has recently gained much attention from researchers, FFIs and policymakers. In Tanzania and Kenya, this debate is amplified by the paradox between the prevalent limited accesses of microcredits by millions of rural active poor despite their availability through financial linkages. While, approximately 2 billion people globally had no access to financial services in 2017 , less than $22 \%$ in Kenya and only $6 \%$ of the population in Tanzania had access to microcredit in 2015 (Facet, 2011; Kimati, 2015) despite financial linkages role of increasing their availability. Drawing from a definition of Pagura and Kristen (2006), a financial linkage is any mutually beneficial partnership between a formal and a less formal institution that results in the expansion of rural financial services. Direct linkages and facilitating linkages are two broad types of financial linkages. While a direct linkage involves a formal institution helping an informal institution diversify its funding sources, facilitating linkage involves an informal institution engaged by a formal one to act on its behalf for a commission. Furthermore, Ju and Jiyoun (2016) propose two more types of linkages according to their purpose: equity linkage and assistance linkage. Equity linkages involve a long term engagement of the formal institution with the informal institution. In some cases, staff of the formal institution will serve on the board of the MFI it has invested in. An assistance linkage pertains to a formal institution issuing a one-time grant or low to zero interest loan for specific technical assistance purposes.

There is a vast literature on argument that through local and global financial linkages with local and international formal financial institutions (FFIs) which are the wholesale funders of MFIs including Microfinance Investment Vehicles (MIVs), Self-Help Groups (SHGs), Socially Responsible Investments (SRI), foreign and local banks, MFIs and FFIs can rejoice a positive synergy (Pagura \& Kirsten, 2006). Financial linkages enable MFIs access loanable funds from FFIs in order to meet their clients' financial demand and retain them (Ishengoma, 2012), expand MFIs market service outreach, reduce MFIs transaction costs of serving the rural poor, broaden MFIs products including insurance, savings, money transfer and sanitation service, and mitigate information mismatch between MFs and MFIs regarding rural poor clientele. According to Pagura and Kirsten (2006), financial 
linkages, a new innovation in microfinance, have a potential to improve the quality of financial products (terms and conditions) and reduce FFIs, cost of serving the rural poor. This innovation is also advocated by Hermes et al (2011) and supported by Temu and Ishengoma (2010) who point out that financial linkages, if properly structured, foster reliable access to microfinance services which can help rural poor borrow, save and invest. Nevertheless, despite the new innovation in expanding microfinance services for the poor over years, millions of poor people around the world in general, in Tanzania and Kenya in particular, still do not have access to microfinance services (Mori \& Olomi, 2011). A number of reasons have been put forward to justify this paradoxical phenomenon. Arne and Hartwig (2014) contend that microfinance is not for everyone because most of the poor do not have required entrepreneurial skills. It was argued that MFIs should be for existing small enterprises in the informal sector, not the very poor without any assets or entrepreneurial skills. However rural poor need more financial service than loans to improve their livelihood (Atieno, 2009). Consequently, microfinance, through financial linkages, has made available a wide range of services such as microinsurance, money transfer, sanitation services and many more whose access do not necessarily call for entrepreneurial skills. Instead, there is much agreement among researchers that the way microfinance products are designed, priced and the conditions associated with financial services limit and sometimes exclude the poor from accessing them despite their availability (Khalil, 2014).

Craig and Valentina (2016) identify five ways rural active poor are either intentionally or unintentionally excluded by MFIs from access to microfinance products. Those ways are staff exclusion, condition exclusion, price exclusion, marketing exclusion and self-exclusion. Staff exclusion occurs when MFIs loan officers discriminate the poor considering that it is risky to service this type of clientele hence discard or discourage their applications. Condition exclusion occurs when the poor fail to meet the conditions associated with the service they need. Price exclusion stems from the phenomenon that clients can only gain access to financial products at prices they cannot afford such as the higher-than-market interest rate and other hidden charges. Marketing exclusion takes place when the poor are deliberately not targeted by a microfinance programme. Self-exclusion happens when the poor participate and exit or do not participate at all because they find out that the products are not designed to respond to their needs, especially in rural areas. Despite their popularity little is known about how financial linkages have enabled MFIs to address supply side barriers to rural poor in order to access financial services. The barriers include the size and kind of collaterals required, unbending loan repayment arrangements, short grace period, the amount of mandatory savings and/or deposit or premium required to access the loan or insurance product in need, the eligibility for the service such as having an existing business instead of startups in case of business loan, higher-than-market interest rate, hidden charges whose effect is to erode the sales surplus, and the inflexible minimum loan size that MFIs have fixed for initial loan (Ellis et al., 2010). Therefore, the aim of this study was they explore how financial linkages between FFIs and MFIs have mitigated the above barriers to access microcredit by rural poor.

\section{Literature Review}

The fundamental motive of forming financial linkages stems from the Information Asymmetry Theory. The theory holds that the asymmetricity of information between parties in a market can be reduced through intermediary market institutions called counteracting institutions in order to mitigate information mismatch between the buyer and the seller (Armendáriz de Aghion \& Morduch, 2010). While FFIs have access to abundant funds but are further removed from rural active poor and lack their information, MFIs operate close to rural active poor and possess quite good information about this clientele and have ample repayment enforcement strategies. However, MFIs lack fund and infrastructure for serving rural active poor adequately (Pagura \& Kirsten, 2006). Furthermore, the researcher borrowed from the Transaction Cost Theory to underscore the establishment of FFIs and MFIs linkages for managing and minimizing their costs or risks by adapting to an uncertain environment (Varghese, 2005). Through such linkages, FFIs reduce operating costs of extending microfinance services in rural areas but serving this clientele is unpredictably risky and results into many tiny transactions which attract high transaction costs. Alternatively, channeling such services through wholesale with MFIs and hence handling few transactions at lower transaction cost while reaching many clients through MFIs retail services reduce FFIs transaction costs.

\subsection{Financial Linkages and Microcredit Availability: Theoretical Perspectives}

The potential of financial linkages of increasing the scope and scale of microfinance services (loan, savings/deposit, money transfer, insurance, etc.) is less debatable by researchers and policymakers (Vargese, 2005). Through financial linkages a number of microfinance institutions (MFIs) and International Development Finance Institutions (IDFIs) investment fund volume have been augmenting over years hence bridging the gap between the demand of financial services and their supply. The capital flows originating from developed 
countries provide key link between local financial needs and international capital sources. Harris (2009) estimates that $29 \%$ of the total of microfinance funding today is channeled internationally (Tomas et al., 2012). It is estimated that only ResponsAbility Global Microfinance Fund (RGMF) had provided US\$1.12 billion loan for 784,500 micro entrepreneurs in 77 countries through more than 250 MFIs, by end of March 2016. However, contrary to microfinance stakeholders expectations, despite the increase in volume of MFIs loanable funds, the gap between financial services, particularly microcredit, demand and supply is still unabridged (Khalil, 2014). The limited access to microcredit by rural active poor is mainly associated with the way they are designed, priced and the conditions associated with their access. The size and kind of collaterals required, loan repayment arrangements and grace period, the amount of mandatory savings and/or deposit or premium required to access the loan or insurance product in need, the eligibility for the service such as having an existing business instead of startups in case of business loan, higher-than- market interest rate, hidden charges whose effect is to erode the sales surplus, and the inflexible minimum loan size that MFIs have fixed for initial loan are among key barriers to access to financial services by rural active poor (Ellis et al., 2010) despite their availability. Even more, rural active poor people are still limited access to microcredit by MFIs loan officers who regard them as potential defaulters. From the theoretical point of view, it is worth noting that some of rural active poor people consider the available financial services not being designed for them as they do not respond to their needs hence opt not to apply for them. From the earlier discussion, though financial linkages unquestionably increase the availability of loanable funds the following six propositions $\left(\mathrm{P}_{\mathrm{i}}\right)$ are put forward:

$P_{1}$ : Financial linkages do not address the collateral barrier to rural active poor access to microcredit.

$P_{2}$ : Financial linkages do not address the loan repayment grace period barrier to rural active poor access to microcredit.

$P_{3}$ : Financial linkages do not address the savings/deposit requirement amount barrier to rural active poor access to microcredit.

$P_{4}$ : Financial linkages do not address the loan eligibility criteria barrier to rural active poor access to microcredit.

$P_{5}$ : Financial linkages do not address the interest rate and hidden charges barrier to rural active poor access to microcredit.

$P_{6}$ : Financial linkages do not address the minimum initial loan size barrier to rural active poor access to microcredit.

\section{Research Methodology}

This is a sequential study which entailed exploratory and survey phases. At this exploratory phase, qualitative data were collected in Tanzania and Kenya. The significant similarities of legal and regulatory regime of Kenya and Tanzania, and their heterogeneity in microfinance industry development made the choice of Tanzania and Kenya relevant to this study. Primary qualitative data were collected through structured interview from 34 financial institutions (FIs) divided into three categories: (1) FFIs and SACCOSs, (2) Microfinance Institutions (MFIs) companies and (3) Savings and Credit Cooperative Societies (SACCOSs) which receive funds from one or more aforementioned FFIs. Furthermore, data were also collected from 74 former and active clients of MFIs and/or SACCOSs, from both Tanzania and Kenya. Financially linked institutions were purposively selected from three regions in Tanzania (Mwanza, Kilimanjaro, and Dar es Salaam) and Kenya (Nairobi, Nakuru, and Gilgil) with the help of Tanzania Association of Microfinance Institutions (TAMFI) and Kenya Association of Microfinance Institutions (AMFI). Clients were selected through snowball sampling technique as MFIs in both countries are banned by law of the land to disclose their clients. 
Table 1. List of Financial Institutions (FIs) whose clients were interviewed

\begin{tabular}{|c|c|c|}
\hline Types of Financial Institutions & Tanzania & Kenya \\
\hline \multicolumn{3}{|l|}{ FFIs and SACCOSs } \\
\hline Credit and Rural Development Bank (CRDB) & $\mathrm{x}$ & \\
\hline Small Entrepreneurs Loan Facility (SELF) & $\mathrm{x}$ & \\
\hline Kenya-Rural Enterprises Program (K-REP) Bank & & $\mathrm{x}$ \\
\hline Co-operative Bank of Kenya (CBK) & & $\mathrm{x}$ \\
\hline Uchumi Commercial Bank (UCB) & $\mathrm{x}$ & \\
\hline Kilimanjaro Co-operative Bank Ltd (KCBL) & $\mathrm{x}$ & \\
\hline OIKO Credit & $\mathrm{x}$ & \\
\hline Fanikiwa Microfinance (Wholesale) & $\mathrm{x}$ & \\
\hline \multicolumn{3}{|l|}{ Savings and Credit Co-operative Societies (SACCOSs) } \\
\hline HIMO & $\mathrm{x}$ & \\
\hline Mshikamano & $\mathrm{x}$ & \\
\hline Ukombozi & $\mathrm{x}$ & \\
\hline UAMKI & $\mathrm{x}$ & \\
\hline UMBWE & $\mathrm{x}$ & \\
\hline SILMA & & $\mathrm{x}$ \\
\hline Amkeni & & $\mathrm{x}$ \\
\hline Dume & & $\mathrm{x}$ \\
\hline Vision Africa & $\mathrm{x}$ & \\
\hline Mwangaza & $\mathrm{x}$ & \\
\hline Nuru ya Maendeleo & $\mathrm{x}$ & \\
\hline CHAWAMPU & $\mathrm{x}$ & \\
\hline WADOKI & $\mathrm{x}$ & \\
\hline Free Area Travelers & & $\mathrm{x}$ \\
\hline MKOLANI & $\mathrm{x}$ & \\
\hline KURUGENZI & $\mathrm{x}$ & \\
\hline Soko Kuu & $\mathrm{x}$ & \\
\hline Wanayanga & $\mathrm{x}$ & \\
\hline UDEA & $\mathrm{x}$ & \\
\hline \multicolumn{3}{|l|}{ Microfinance Institutions (MFIs) Companies } \\
\hline MUSONI & & $\mathrm{x}$ \\
\hline ECLOF & & $\mathrm{x}$ \\
\hline Fanikiwa (Retail) & $\mathrm{x}$ & \\
\hline Letshengo & & $\mathrm{x}$ \\
\hline Rafiki & & $\mathrm{x}$ \\
\hline SISDO & & $\mathrm{x}$ \\
\hline Ebenezer & $\mathrm{x}$ & \\
\hline Vision Fund & $\mathrm{x}$ & \\
\hline
\end{tabular}

Content Analysis technique was used to analyze the qualitative data. This technique entailed systematically 
classifying phrases and sentences into a series of meaningful categories through latent coding which is the analysis of the more implicit meaning of text or theme (Kalof L. et al., 2008). It is worth considering that, in order to avoid excessive repetition, in the following sections of this paper, both MFIs and SACCOSs will be referred to as MFIs.

\section{Research Findings and Discussion}

The study findings have established that linkages between formal and informal financial institutions certainly to increase the flow of loanable funds from various FFIs such as development banks, NGOs, to name but a few to MFIs. Linkages have also increased the scope of services offered by MFIs for rural active poor to increase their choice. Apart from deposit/savings, money transfer and microinsurance products - though at its infancy stage-MFIs have managed to diversify the types of loans they offer. Apart from traditional business loans, financial linkages have enabled MFIs to offer loan for agriculture, education, livestock, emergency and many more. More interestingly, some MFIs have introduced water, sanitation, and hygiene services (WASH) loan whereby MFIs construct water, latrines and stoves for clients on credit and clients repay on installment basis. Moreover, the study reveals that financial linkages have enhanced the expansion of microfinance services for rural active poor. As one of the prerequisite of loan, FFIs contractually require MFIs to align with FFIs' mission and vision including lending to rural active poor otherwise they would not receive funds. Financial linkages are beneficial for both FFIs and MFIs in the sense that FFIs reduce transaction cost through wholesale lending and default risk of serving the rural active poor. MFIs have more information about rural clients and better repayment enforcement mechanisms than FFIs do. In a nutshell, financial linkages increase availability of microfinance services for MFIs clients in general, and rural active poor in particular. However, despite the availability of microfinance services, their accessibility and sometimes their affordability is still limited by a number of factors such as types and size of required collaterals, mandatory savings/deposit amount, unbending repayment arrangement and short grace period, higher-than-market interest rate and premium, inflexible minimum initial loan size are among key factors limiting rural active poor from accessing financial services. More appealingly, such factors are interrelated. The access to inflexible initial loan requires that a client owns an existing business, in the case of business loan and collaterals such as social collaterals - whose value may not suffice to secure the loan amount. Subsequent loan amount is determined by the amount of mandatory savings/deposits the applicant has made. The savings/deposits that the applicant had to make from the business were eroded by initial loan high interest rates and hidden charges. Additionally, as the repayment and grace periods were too short to enable the applicant to generate enough cash to repay due loan installments, the applicant uses a fresh loan to repayment an outstanding loan. The above barriers to financial services are elaborated below.

\subsection{Collaterals and Microcredit Accessibility}

Collaterals are one of the $5 \mathrm{Cs}$ which constitute a method of evaluating loan applicant credibility, i.e., borrower's collateral, character, capital, capacity and conditions. Study findings reveal that the lack of required collaterals has been one of key barriers to Tanzanian and Kenyan rural active poor access of the loan from both formal and informal financial sector. Physical collaterals such as land title deed and log books are more preferred by lending institutions while most of the rural active poor have no registered land. MFIs have responded to this constraint by introducing a group lending methodology whereby group members co-guarantee hence do not pledge physical collaterals to the MFIs. Nevertheless, the study has revealed that group members require that any group member intending to borrow has to pledge social collaterals (household furniture, appliances, equipemnts) before they guarantee him/her. In case group members are not satisfied with available social collaterals, they do not guarantee the applicant and definitely the applicant cannot access the loan. Cases of denial of membership from group members to active poor people were also reported. In such cases, a prospective borrower cannot be guaranteed hence cannot access the loan. In this regard, despite that the financial linkages succeeded to increase the amount of loanable fund, there was no empirical evidence that they contributed in mitigating the collateral barriers to microcredit accessibility.

\subsection{Loan Repayment Grace Period and Microcredit Accessibility}

The majority of MFIs interviewed were offering a grace period of one week. The client starts repaying the loan one week after the loan was issued. Loan installments repayments are made during weekly group members meetings. Clients who were interviewed complained that it could happen that they could not accumulate the required installment amount during that week due to market fluctuation. Consequently, they had to use the loan for making the repayment of the required weekly installment. Even more, they could not travel for more than a week as they had to attend every weekly meeting and repay their due weekly installments. Therefore, they could not travel at remote villages where produces are purchased at cheaper price but yielded higher profit margin. If 
one does so and fails to make a scheduled weekly installment, one has to wait for the following weekly group members meeting and repay two installments all together. As a result, the client cannot obtain all the two installments at the same time and the burden keeps on accumulating as the group, on behalf of the MFI, refuses to receive less than the due amount. From MFIs and FFIs perspective, financial linkages had played a great role in increasing the amount of loanable fund but there was no empirical evidence that they contributed to increase the repayment and grace period of the loan.

\subsection{Savings/Deposits Requirement and Microcredit Accessibility}

Clients' savings/deposits are compulsory for loan eligibility of all MFIs which were interviewed. The amount of client savings or deposits is the determinant of the size of loan that client is allowed to receive. For most MFIs, a client is allowed to apply for a loan not exceeding three times his/her savings/deposit. In most cases, the client cannot afford to accumulate required savings for the loan size in need at right time before the window of opportunity closes. Moreover, in some other cases, if a client applies for a loan exceeding the MFI threshold, the latter forwards the application of the funder and the client is required by the funder through the MFI to make a deposit not less than $50 \%$ of the size of the loan he applies for. In so doing, the client pays the required $50 \%$ of the loan out of his/her savings or else it is deducted from the applied loan. Consequently, the client receives small loan than the amount he budgeted and the received amount is no longer enough for the intended activity. As a result, the client invests the money in unplanned activity which, for many clients the researchers interviewed, fails to timely generate the due repayment installment and hence results into defaults. Or else, a client may borrow with interest from a fellow so as to get a required deposit and secure the loan in need. Once the loan is disbursed, the client reduces it to repay the loan (principal with interest) from the fellow. Consequently, the reduced loan amount cannot satisfy the loan need, which in most cases had led to misuse of loan, multiple borrowing and/or default.

\subsection{Eligibility Criteria for Microcredit and Its Accessibility}

In regard to eligibility for loan, study findings have established that despite the availability of loanable funds through linkages, rural active poor still have limited access to business loans because MFIs provide loan for existing businesses. Rural active poor, no matter how feasible their business ideas, are not eligible for the loan to implement their viable ideas as the loan is not for startups. Hence the window of opportunity closes before the client accesses the capital to implement the idea. FFIs had, in some cases, stipulated that lending to the rural active poor is one of the prerequisite for an MFI to get a loan from FFIs. However, MFIs had to stick to their loan application criteria to ensure that the loan of the client is repaid and remitted to the funder. Therefore, the underlying condition such as having an existing business was a significant hindrance to microcredit accessibility.

\subsection{Interest Rate, Hidden Charges and Microcredit Accessibility}

Study findings under this topic revealed a combination of interesting and unfortunate incidences behind MFIs business. Financial linkages certainly increase the availability of MFIs loanable funds and MFIs have to repay back the principal with interest of FFIs. MFIs borrowing cost including a profit margin to be earned by an MFI are borne by the last consumer, i.e., the MFIs client. This supply chain from MFs to client through MFIs results into higher interest rate that an MFI client has to bear. Moreover, financial linkages have led to different interest rates charged by the same MFI for its different clients hence confusing clients who repay different amount for equal loan size. MFIs charge clients higher-than-market interest rates up to $60 \%$. On top of that, if not inclusive, the applicant has to pay application fee, legal fee, and loan insurance premium - sometimes undisclosed for clients hence labeled hidden charges - and cover the cost of borrowing from FFIs, transaction costs resulting from small loans to clients, their operation cost and default risk. In some cases, FFIs set a maximum interest rate that MFIs should not exceed when lending to their clients. However, MFIs either deny credit with applicants or still charge higher than the ceiling interest rates and submit maneuvered reports to FFIs.

In some cases, FFIs receive many loan applications from their allied MFIs. Due to this high demand, MFIs managers have to induce FFIs' loan officers so that they receive special consideration when deciding which MFIs receive a loan earlier. Consequently, the enticement paid by MFI manager has to be recovered through hidden charges for clients. High interest rates and hidden charges erode the profit margin which clients generate. Consequently, borrowing becomes a survival rather than a poverty reduction strategy. Most of these cases have so far resulted into financial burden for clients which translated into repayment default. As a result, clients pledged social collaterals were confiscated by MFIs or group members, which leads to MFIs clients' suicide cases. The study has also found out new innovation in microfinance where NGOs, through MFIs, provide fully fitted water tanks, construct fully fitted shallow wells and water pans, sanitation and hygiene infrastructures (WASH products), solar panels and home appliances (Rembesha Nyumba product) for their clients who have to 
repay on installment basis. The new MFIs products were eagerly embraced by clients just to find that they were far more expensive than market price and drop the products. MFIs received the loan from the funder at sizeable interest rate. In return, MFIs had to charge much higher interest rate for their clients to generate a profit. In this regard, financial linkages were considered to amplify the interest rate barrier instead of mitigating.

\subsection{Minimum Initial Loan Size and Microcredit Accessibility}

From the empirical point of view, the way microfinance services are designed limits their access by the rural active poor. Some MFIs, particularly Savings and Credit Co-operative Societies (SACCOSs) operate in rural areas. Through linkages, they have managed to expand microfinance products to rural active poor. However, those products are not perceived by rural active poor as designed for them because they do not respond to their needs. As a matter of facts, MFIs have set a minimum loan size that a client can borrow an initial loan of Ksh10, 000 (an equivalent of around Tshs 190,000) in Kenya and Tshs 50,000 in Tanzania. Clients interviewed in both countries in this regard expressed their limitation to access such available loanable funds because they need an initial loan which is less than the set minimum loan size but are compulsorily required to take a loan higher than the amount they could manage better, greater than their plan, while they had no prior idea of how to feasibly use the loan excess. Consequently, they invest the excess into an unintended activity which resulted into failure of repaying the loan. Alternatively, a client had to agree with a fellow to lend him/her the excess loan. On the repayment date, as his/her name is not registered nor recognized by the MFIs, the fellow is less concerned with the repayment hence shifts the burden to MFIs' client who has to hardly clear the debt s/he did not incur. Sad stories of clients' suicide due to failure of repaying the loan for fear of social shame and loss of the little assets they had were reported. Such incidences make rural active poor reluctant to seek for microcredit despite their availability. There was no empirical evidence of financial linkages intervention to alleviate this challenge.

\section{Conclusion and Policy Implication}

\subsection{Conclusion}

The findings of this exploratory phase study have preliminarily established that, if properly structured, financial linkages between formal and informal financial institutions not only enable MFIs increase loanable funds outreaching rural active poor but also diversify their products so as to broaden clients' choice. Improving terms and conditions associated with financial services, was also at the heart of MFIs financial linkage motives. However, contrary to clients' expectations, rural active poor are still constrained to access microcredit despite their availability. This study has established the type and size of collaterals that MFIs clients are required to pledge that they secure the loan, the amount of mandatory saving/deposit which determine the size of loan for applying, high interest rates, hidden charges on loan and insurance, unbending repayment arrangement, short loan grace period and inflexible size of initial loan are key barriers to rural active poor access for microcredit. Study findings at great extent are paradoxical with financial linkage promise to improve terms and conditions associated with access to financial services. Instead, the study findings are supported by Craig and Valentina (2016) literature over the ways rural active poor are either intentionally or unintentionally excluded by MFIs from access of financial services. From theoretical point of view, information asymmetry theory and transaction cost theory which motivate financial linkages establishment have insignificant favorable effect on MFIs product design, price, and conditions associated with financial services. In a nut shell, financial linkages have irrefutably succeeded in increasing MFIs loanable funds and diversify microfinance services but have evidently achieved less in addressing the barriers limiting rural active poor to access those services. It is the author's recommendation for FFIs to set fund eligibility requirements that compel MFIs to design favorable terms and conditions which encourage the active poor access microcredit. The recommended terms and conditions include customizing the type and size of collaterals that MFIs clients are required to pledge for securing the loan, to reduce the amount of mandatory saving/deposit required to determine the size of loan to apply, FFIs to lend at lower interest rates to MFIs which, in turn, will have to reduce the interest rates to charge to their clients, to evaluate and disclose the current hidden charges on loan and insurance, to customize the repayment arrangement according to the clients convenience, to increase loan grace period and to customize the size of initial loan.

\subsection{Policy Implication}

Financial linkages innovation has an incontestable financial service outreach potential for rural active poor. Thus, from the study findings, the author put forward to the policymakers to revisit the national microfinance policy in Tanzania and Kenya not only to establish regulatory policy and promote the contribution of financial linkages to assist MFIs achieve their social and commercial mission of financial service outreach but also mitigate the identified barriers to microcredit access by the rural active poor. 


\section{References}

Armendáriz de Aghion, B., \& Morduch, J. (2010). The economics of microfinance (2nd ed.). Cambridge: MIT Press.

Arne, D. C., \& Hartwig M. (2014). Microfinance: Influence of Competion on Outreach. Ghent University.

Atieno, M. (2009). Linkages, Access to Finance and Performance of Small - Scale Enterprises in Kenya. World Institute for Development Economic Research.

Craig, B., \& Valentina S. (2012). Financial Citizenship: Rethinking the State's Role in Enabling Individuals to Save. Friends Provident Foundation.

Ellis, K., Lemma A., \& Rud, J. (2010). Investigating the Impact of Access to Financial Services on Household Investment. UK: Oversee Development Institute.

Facet, T. (2011). Tanzania Microfinance Country Scan, Final Report. The Netherlands, Washington: Zeit.

Harris, S. D. (2009). State of the Microcredit Summit Campaign. Washington Publication.

Hermes, Niels, Lensink, Rober Meesters, \& Aljar. (2011). Outreach Efficiency of Microfinance Institutions. World Development, 9(6). https://doi.org/10.1016/j.worlddev.2009.10.018

Ishengoma, E. K. (2012). Linkage Banking and Outreach: A Case of Microfinance Cooperatives in Tanzanian Case. Business Management Review Journal, 16, 140-160.

Khalil, E. A. (2014). Challenges of Jordan's Microfinance from Points of Views of Microcredit Managers: Empirical Study. Asian Transactions on Basic and Applied Sciences, 4(2).

Kimati, A. F. (2015). The Challenges confronting Small Scale Businesses in Accessing Microfinance Services from MFIs. Case Study: Rural Tanzania. International Journal of Academic Research in Business and Social Sciences, 5(1).

Pagura, M., \& Kirsten, M. (2006, March). Formal-informal financial linkages: Lessons from developing countries. Small Enterprise Development.

Pyum, H., \& Jiyoun, A. (2016). Capital and Credit Market Integration and Real Economic Contagion During the Global Financial Crisis. Journal of International Money and Finance, 1(1).

Seibel, H. D. (2005). Linkages between Banks and Microfinance Institutions in Mali: A case study.

Temu,S. S., \& Ishengoma, E. K. (2010). Financial Linkages and Performance of Rural Microfinance Cooperatives:Tanzania Case. Indian Journal of Economics and Business, 2.

Thomas, H., Karel S., Martina, D., \& Alena, N. (2012). Transforming 3rd World Debt into Microfinance Liabilities: The Odious Debt Becoming an Opportunity. International Journal of Advances in Management and Economics, 1(5), 167-174.

\section{Copyrights}

Copyright for this article is retained by the author(s), with first publication rights granted to the journal.

This is an open-access article distributed under the terms and conditions of the Creative Commons Attribution license (http://creativecommons.org/licenses/by/4.0/). 